\title{
KRT19 Gene
}

National Cancer Institute

\section{Source}

National Cancer Institute. KRT19 Gene. NCI Thesaurus. Code C38195.

This gene plays a role in cytoskeletal regulation and the corresponding cellular morphology. 